\title{
Dermatoglyphic patterns of goitrous children in endemic iodine deficiency area
}

\author{
Martira Maddeppungeng, MD; R Satriono, MD
}

\begin{abstract}
Background Goiter mapping on elementary school students in 1998 showed that the prevalence of endemic goiter was still high at Enrekang regency, South Sulawesi despite various programs to manage this problem. This raised questions if there were any other factors that contribute to the occurrence of goiter e.g. genetic factor, which can be assessed indirectly by dermatoglyphic pattern.

Objective To determine the dermatoglyphic pattern in goitrous children and compare it to normal children.

Methods A cross sectional study was done to investigate the correlation between goiter and dermatoglyphic patterns on 115 elementary school students at Anggeraja and Baraka subdistricts, Enrekang regency. Dermatoglyphic patterns of finger tips of both hands and right hallux were scanned using Prolink scanner with Maximum Resolution of $19200 \times 19200 d p i$ and interpreted using photo/image editing computer program.

Results Seventy two $(62.6 \%)$ of 115 children were goitrous, seventy $(97 \%)$ were of stage1, and $2(3 \%)$ of stage 2 . No significant difference was found in dermatoglyphic patterns between normal and goitrous children. Tibial loop pattern of the right hallux tended to be more frequent in goitrous children than that of normal children, but it was not statistically different (in level of significancy of $0.05)$ compared to normal children $(p=0.085)$.

Conclusions This study indicates that the possibility of the role of genetic factor in the development of goiter in endemic area is unlikely [Paediatr Indones 2004;44:117-120]
\end{abstract}

Keywords: Dermatoglyphic pattern, goitrous children, endemic iodine defficiency area, genetic factor.

I $\mathrm{n}$ the Province of South Sulawesi, a goiter mapping on elementary school students in 1998 showed that the prevalence of endemic goiter was still high at Enrekang regency, especially very high at Baraka and Anggeraja subdistricts. ${ }^{1}$

Iodine-fortified salt and oil program had been started nationally in $1976 . .^{2-4}$ Despite various trials in managing this problem, the prevalence of iodine deficiency-related disorders, assessed based on the enlargement of thyroid gland, was still high. This raised questions if there were any other factors that contribute to the occurrence of goiter. ${ }^{1,2}$

According to a survey of iodine-deficiency-related disorders in 1998, about 87 million Indonesians inhabited the area at-risk of iodine deficiency; 20 million suffered from goiter and 290,000 suffered from cretinism due to iodine deficiency. ${ }^{5}$ Iodine deficiency and goitrogenic substances, genetic, or autoimmune factors may cause endemic goiter. ${ }^{2,6}$ Dermatoglyphic pattern, scientifically described for the first time by Galton in the past century, has been proven to be strongly controlled and regulated by genetic factor. Dermatoglyphic pattern is fully developed within the first trimester of pregnancy and will not change until birth. ${ }^{7,8}$ One of the etiologies of goiter is genetic factor. If there are special dermatoglyphic patterns on goitrous patients revealed, then it may be used as supportive measure to establish diagnosis or predict the occurrence of goiter. This study was carried out to investigate the dermatoglyphic patterns of goitrous patients. To our knowledge, there had not been such studies before.

From The Department of Child Health, Medical School, Hasanuddin University, Makassar.

Reprint request to: Satriono, Department of Child Health, Medical School, Hasanuddin University, Jl. Perintis Kemerdekaan KM 11, Makassar 90245. Tel. 0411 453455, email: satriono@upandang,wasantara.net.id. 


\section{Methods}

This cross-sectional study was conducted at Enrekang regency, South Sulawesi, from March to June 2001. Subjects of the study were 120 elementary school students (aged 6-11.5 years) at endemic area. Subjects were selected using convenience sampling method.

Assessment of the size of the thyroid gland was done by palpation according to the method recommended by WHO. ${ }^{9}$ Dermatoglyphic pattern examination was done by using Prolink scanner (ProSKU42U Winscan True 42-Bit Color Optical Resolution: 600 x 1200 dpi, Max. Resolution: 19200 x 19200 dpi) as following: Both hands and right foot to be examined were washed and wiped with clean towel until they were completely clean and dry. The glass plate of the scanner was cleaned with dry clean cloth. The hands of the subject were placed on the glass plate with both palms pressed smoothly in order to have a clear image of the dermatoglyphic patterns and then the right foot was treated with similar manner. Dermatoglyphic readings were done with personal computer by using Microsoft Photo Editor and Corel Photo Paint Version 9.

The examples of dermatoglyphic pattern obtained by this method can be seen in Figure 1. The data were analyzed using univariate analysis for fre- quency distribution presented in table or chart. The differences of dermatoglyphic patterns between goitrous and normal children were analyzed using chi square test. Stat Calc Program of Epi Info Version 6.0 was used to perform the chi square calculation with $\mathrm{p}<0.05$ as the level of significance.

\section{Results}

There were 120 elementary school children who underwent dermatoglyphic examinations comprising of 77 goitrous and 43 normal children. Five goitrous children were excluded because the dermatoglyphic patterns were difficult to identify. The final sample consisted of 115 children, 72 (62.6\%) goitrous and 43 (37.4\%) non goitrous children. Among 72 goitrous children, 40 (51\%) and 32 (44\%) were male and female, respectively. The number of goitrous children according to the grade of the disease is seen on Figure 2.

The frequency distribution of dermatoglyphic pattern of fingertips can be seen in Table 1, while the frequency distribution of dermatoglyphic pattern of right hallux in normal and goitrous children could be seen in Table 2 .

Chi-square analysis of dermatoglyphic pattern of normal and goitrous children is seen in Tables 3 and 4 .
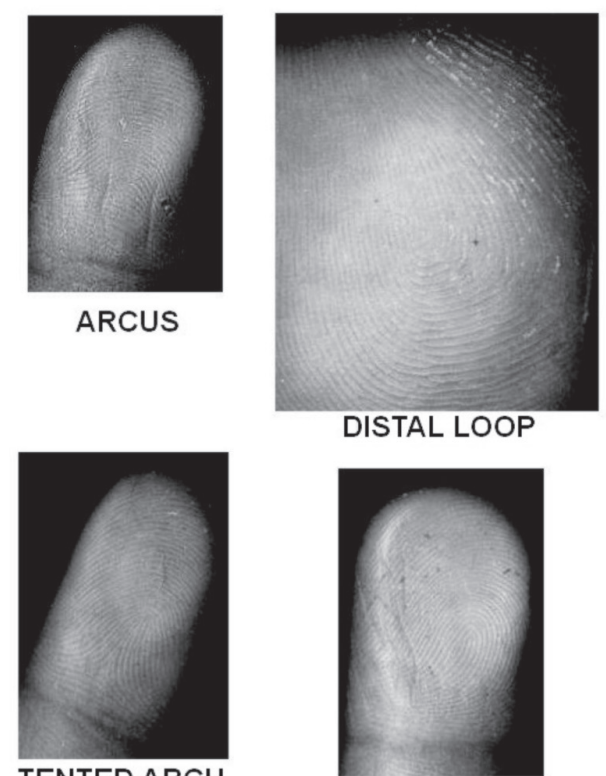

TENTED ARCH

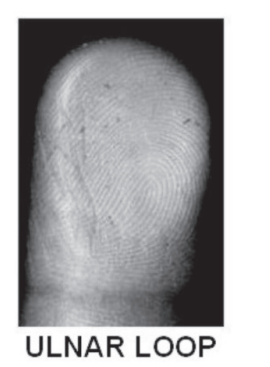

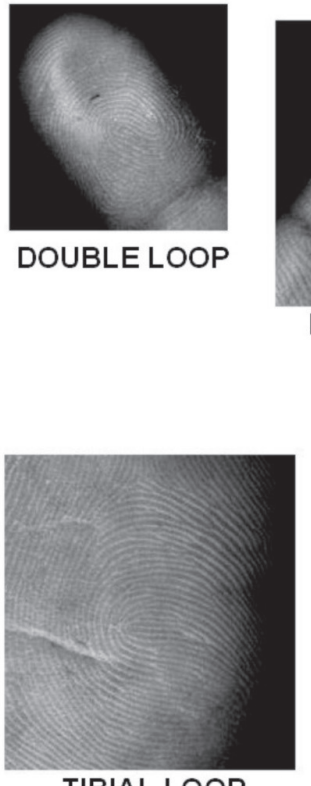
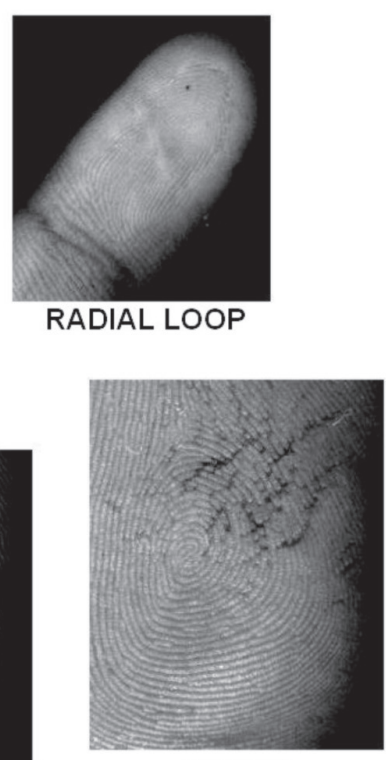

WHORL

Figure 1. Dermatoglyphic patterns obtained by computer scanner method. 


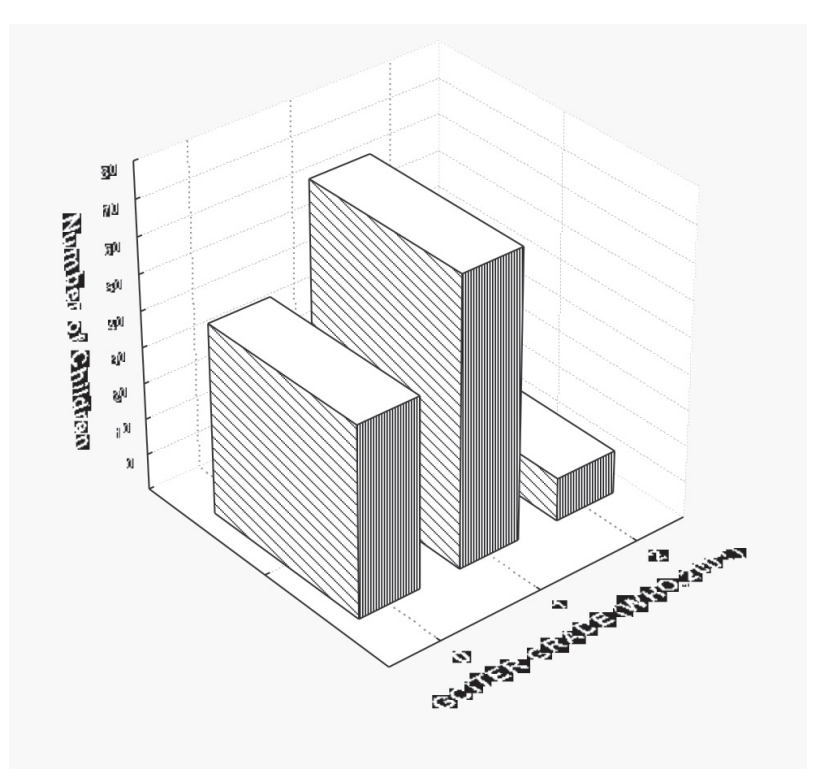

Figure 2. The number of goitrous children according to the grade of the disease (WHO, 2001)
Table 3 shows that there was no statistical difference $(\mathrm{p}>0.05)$ in total dermatoglyphic pattern in nomal and goitrous children.

Table 4 shows that right hallux dermatoglyphic pattern in goitrous and normal children was not statistically different $(\mathrm{p}>0.05)$.

\section{Discussion}

A cross sectional study to find out the relation between goiter and dermatoglyphic pattern had been carried out on elementary school students in an endemic goiter area i.e., Angeraja and Baraka subdistricts, Enrekang regency. There were 120 children (77 goitrous and 43 normal children) who were brought to Makassar for a dermatoglyphic examination. Five goitrous children were excluded because their dermatoglyphic pattern could not be identified,

TABle 1. Frequency distribution of DeRmatoglyphic pattern of Fingertips (BOth hands)

\begin{tabular}{lcccccc}
\hline Pattern & \multicolumn{2}{c}{$\mathbf{M}$} & \multicolumn{2}{c}{$\mathbf{F}$ Total } \\
\hline & $\begin{array}{c}\text { Normal (\%) } \\
\mathbf{n = 1 9}\end{array}$ & $\begin{array}{c}\text { Goiter (\%) } \\
\mathbf{n = 4 0}\end{array}$ & $\begin{array}{c}\text { Normal (\%) } \\
\mathbf{n = 2 4}\end{array}$ & $\begin{array}{c}\text { Goiter (\%) } \\
\mathbf{n = 3 2}\end{array}$ & $\begin{array}{c}\text { Normal (\%) } \\
\mathbf{n = 4 3}\end{array}$ & $\begin{array}{c}\text { Goiter (\%) } \\
\mathbf{n = 7 2}\end{array}$ \\
\hline $\mathbf{W}$ & $65(42.8)$ & $132(41.3)$ & $66(34.4)$ & $98(38.4)$ & $131(38.1)$ & $230(39.9)$ \\
$\mathbf{U}$ & $74(48.7)$ & $176(55.0)$ & $117(60.9)$ & $139(54.5)$ & $191(55.5)$ & $315(54.7)$ \\
$\mathbf{R}$ & $2(1.3)$ & $4(1.3)$ & $2(1.0)$ & $4(1.6)$ & $4(1.2)$ & $8(1.4)$ \\
$\mathbf{A}$ & $3(2)$ & $2(0.6)$ & $2(1.0)$ & $11(4.3)$ & $5(1.5)$ & $13(2.3)$ \\
TA & - & $3(0.9)$ & $2(1.0)$ & - & $2(0.6)$ & $3(0.5)$ \\
DBL & $8(5.3)$ & $3(0.94)$ & $3(1.6)$ & $3(1.2)$ & $11(3.2)$ & $6(1.0)$ \\
Total & $152(100)$ & $320(100)$ & $192(100)$ & $255(100)$ & $344(100)$ & $575(99,8)$ \\
\hline
\end{tabular}

Note : W(whorl); U(ulnar loop); R(radial loop); A (arch); TA(tented arch); DBL (double loop); M (male); F(female)

TABle 2. FReQuency distribution of DeRmatoglyphic PATTERN ON RIGHT HALLUX

\begin{tabular}{llllll}
\hline Pattern & W & O & DL & TBL & Total \\
\hline Goiter & 16 & 5 & 43 & 8 & 72 \\
Normal & 8 & 4 & 30 & 1 & 43 \\
\hline
\end{tabular}

Note: O (Others);TBL (Tibial loop); DL (Distal loop); W (whorl)

TABle 3. $X^{2}$ test of total dermatoglyphic patterns of NORMAL AND GOITROUS CHILDREN

\begin{tabular}{lllll}
\hline Pattern & Normal & Goiter & $\mathbf{X}^{\mathbf{2}}$ & $\mathbf{p}$ \\
\hline $\mathrm{W}$ & 131 & 230 & 0.26 & 0.612 \\
$\mathrm{U}$ & 191 & 315 & 0.02 & 0.880 \\
$\mathrm{R}$ & 4 & 8 & 0.00 & 0.996 \\
$\mathrm{~A}$ & 5 & 13 & 0.37 & 0.542 \\
$\mathrm{TA}$ & 2 & 3 & 0.12 & 0.730 \\
$\mathrm{DBL}$ & 11 & 6 & 4.38 & 0.363 \\
\hline Total & $\mathbf{3 4 4}$ & $\mathbf{5 7 5}$ & &
\end{tabular}

Note : W (whorl); U (ulnar loop); R (radial loop); A (arch); TA (tented arch); DBL (double loop). therefore finally the total sample was 115 children, consisted of 43 normal children and 72 goitrous children.

Dermatoglyphic examination was performed simultaneously by scanning method on all 10 fingers. In this study, dermatoglyphic pattern of the thumb could not be identified due to the bad position of thumbs.

TABle 4 . X $X^{2}$ TESt of halluX DeRmatoglyphics PATtern OF NORMAL AND GOITROUS CHILDREN

\begin{tabular}{lllll}
\hline Pattern & Normal & Goiter & $\mathbf{X}^{2}$ & $\mathbf{p}$ \\
\hline $\mathrm{W}$ & 8 & 18 & 0.32 & 0.573 \\
$\mathrm{O}$ & 4 & 5 & 0.01 & 0.922 \\
$\mathrm{DL}$ & 30 & 43 & 0.78 & 0.377 \\
$\mathrm{TBL}$ & 1 & 8 & 1.79 & 0.085 \\
Total & 43 & 72 & & \\
\hline
\end{tabular}

Note: O (Others); TBL (Tibial loop); DL (Distal loop); W (whorl) 
Congenital goiter can be caused by many etiologies. Gen mutation which can cause defect in TSH receptor, thyroglobulin and sodium-iodine symporter results in congenital goiter. ${ }^{10}$ Dermatoglyphic pattern will never change since birth. ${ }^{8,10-12}$ Its forming process in intrauterine is still unknown. Different dermatoglyphic pattern can be seen in chromosome 21 disorder, trisomy 18 and chromosome aberration, non-genetic development disorder (rubella, cytomegalovirus infection and thalidomide), improper dermatoglyphic development on extremities e.g., polydactily, syndactily, etc., monogenetic or polygenetic disease. ${ }^{8,11}$

Fingerprint is a pattern on the skin of the tip of the finger which develops since embryonic period (Losech 1971) and persists without any change till death. This pattern is characteristic in humans as a reflection of his genes. Therefore, fingerprint can be used as personal stamp. Any change or mutation on chromosomes will make fingerprint pattern differ from normal. ${ }^{13}$

Overall, this study found that statistically there was no difference of dermatoglyphic patterns in goitrous and normal children. It might be happened because our sample was small and we did not classify the etiology of the goiter as genetic or non genetic. On other hand, normal children might have genetic change which could involve dermatoglyphic pattern but the goiter had not manifested yet.

It seems that genetic factor was not a risk in that area which had been declared as an endemic iodine deficiency area.

Althought tibial loop in right hallux of goitrous children is more common than that of normal $(11.1 \%$ compared to $2.3 \%$ ), it was not statistically different $(\mathrm{p}=0.085$. (See Table 4)

We concluded that there was no significant difference in dermatoglyphic pattern between goitrous and normal children which indicated that the possibility of the role of genetic factor in the development of goiter in this endemic area was unlikely. Further studies to find out the relation between dermatoglyphic pattern and goiter especially in genetic goiter cases are needed.

\section{References}

1. Dachlan DM, SatrioneR. Survei pemetaan gangguan akibat kekurangan iodium di Sulawesi Utara, Tenggara, Selatan, Tengah. Makassar: Pusat Gizi dan Pangan UNHAS dengan Depkes RI; 1997/98. p. 546

2. Kartono D. Garam beryodium dan gondok endemik. Medika 1993;8:35-7.

3. Guyton AL, Hall JE. Textbook of medical physiology. $9^{\text {th }}$ ed. Philadelphia: WB Saunders Co; 1996. p. 945-56.

4. Yusuf I, Satriono R, Kaelan C. Iodium dan GAKI. Disampaikan pada Semiloka Penelitian; 21 Juli 1995; Makassar, Indonesia.

5. Anonymous. Dua puluh juta penduduk kekurangan iodium. Kompas 2001 April 11; Page 10.

6. Lazarus JH, Obuobie K. Thyroid disorders: an update. Postgrad Med J 2000;76:529-36.

7. Syahrum MH, Suhana N, Warouw ED. Dermatoglifi telapak tangan pada penderita diabetes mellitus. Maj Kedok Indon 1993;43:501-05.

8. Holt SB. The significance of dermatoglyphics in medicine: a short survey and summary. Clin Paediatr 1973;12:471-84.

9. WHO, UNICEF and ICCIDD 2001. Assessment of the iodine deficiency disorders and monitoring their elimination. Geneva: WHO publ. WHO/NHD/01.1. p. 1107.

10. Holmes LB. General clinical principles in genetic disorders. In: Behrman RG, Kliegman RM, Arvin AM, editors. Nelson texbook of pediatrics. $14^{\text {th }}$ ed. Philadelphia: WB Saunders Co; 1998. p. 281-2.

11. Rafiah RS, Syahrum MH. Dermatoglifi dan hubungan dengan penyakit yang disebabkan bukan karena aberasi kromosom. Maj Kedok Indon 1991;41:44-6.

12. Alter N, Schulenberg R. Dermatoglyphics in the rubella syndrome. JAMA 1966;93-6

13. Surjadi S, Satmoko, Rafiah RST. Pola sidik jari dan total ridge count kelompok residivis di Indonesia. Maj Kedok Indon 1984;34:101-3. 